\title{
MENINGKATKAN PEMAHAMAN RESIKO PERILAKU SEKSUAL PRA NIKAH MELALUI LAYANAN INFORMASI DENGAN MEDIA AUDIO VISUAL SISWA SMA NEGERI 2 MEMPAWAH
}

\author{
Hendrik $^{1)}$, Ratini ${ }^{2)}$ \\ ${ }^{1)}$ IKIP PGRI Pontianak, Pontianak, Indonesia \\ E-mail: iklilzaki@gmail.com \\ ${ }^{2)}$ IKIP PGRI Pontianak, Pontianak, Indonesia \\ E-mail: ratini1996@gmail.com
}

\begin{abstract}
Abstrak. Tujuan penelitian ini adalah 1) mengetahui pemahaman resiko perilaku seksual pra nikah sebelum diberikan layanan informasi dengan media audio visual siswa SMA Negeri 2 Mempawah, 2) mengetahui pelaksanaan layanan informasi dengan media audio visual meningkatkan pemahaman resiko perilaku seksual pra nikah siswa SMA Negeri 2 Mempawah, 3) peningkatan pemahaman resiko perilaku seksual pra nikah melalui layanan informasi dengan media audio visual siswa SMA Negeri 2 Mempawah. Metode penelitian ini adalah penelitian tindakan Bimbingan dan Konseling. Subjek uji coba terbatas terdiri dari 33 siswa. Hasil penelitian menunjukkan bahwa pemahaman resiko perilaku seksual pra nikah melalui layanan informasi dengan media audio visual siswa SMA Negeri 2 Mempawah meningkatkan pemahaman resiko perilaku seksual pra nikah, melalui 4 tahapan dalam penelitian tindakan bimbingan dan konseling, yaitu: 1) perencanaan, 2) pelaksanaan, 3) pengamatan, dan 4) refleksi. Berdasarkan hasil penelitian menunjukkan terdapat peningkatan skor awal 57\% mengalami peningkatan setelah dilaksanakan tindakan siklus I menjadi $65 \%$ dan dilaksanakan tindakan siklus II meningkat lagi dengan persentase $77 \%$. Dari peningkatan hasil penelitian di atas disarankan guru bimbingan dan konseling dapat menggunakan layanan informasi dengan media audio visual untuk meningkatkan pemahaman resiko perilaku seksual pra nikah.
\end{abstract}

Kata Kunci: Pemahaman Resiko Perilaku Seksual Pra Nikah; Layanan Informasi; Media Audio Visual

\section{Pendahuluan}

Sesuai amanat [1] yang mengatakan "Pendidikan adalah usaha sadar dan terencana untuk mewujudkan suasana belajar dan proses pembelajaran agar peserta didik secara aktif mengembangkan potensi dirinya untuk memiliki kekuatan spiritual, keagamaan, pengendalian diri, kepribadian, kecerdasan, akhlak mulia, serta keterampilan yang diperlukan dirinya, masyarakat, bangsa dan negara”. Pendidikan merupakan hal sangat penting tentunya bagi peserta didik untuk menjadikan diri sebagai pribadi yang cerdas dan perilaku baik sebagai penerus bangsa. Melihat perkembangan zaman yang begitu pesatnya sehingga dituntut peserta didik untuk memiliki akhlak yang baik, untuk menyiapkan dirinya dalam berkehidupan di masyarakat agar mampu menghadapai tantangan era globalisasi yang bebas tanpa batas.

Era globalisasi sekarang ini membuat pergaulan remaja semakin tanpa mengenal batasan dan norma. Selain itu globalisasi menyebabkan aksesbilitas remaja terhadap pornografi menjadi lebih mudah. Ribuan situs porno di internet serta media-media lain, seperti tabloid porno, komik porno, VCD porno dan lain-lain yang beredar bebas di sekeliling remaja menjadi salah satu stimulant pergeseran perilaku para remaja saat ini. Fase remaja yang berada dalam periode krisis memeiliki sifat serba ingin tahu. Informasi yang setengah-setengah membuat mereka akan semakin ingin tahu apa itu. Remaja membutuhkan informasi 
yang tepat tidak setengah-setengah karena hal itu hanya menimbulkan rasa penasaran.

Menurut [2] perilaku seksual pada remaja sering kali mencemaskan para orang tua, guru, masyarakat, pemerintah, dan masyarakat. Di dalam dunia pendidikan khususnya dikalangan remaja merupakan generasi harapan namun disisi lain menghadapi banyak permasalahan yang bukan dan tidak mungkin akan menggangu perkembangan fisik maupun psikologis mereka selanjutnya. Di antara persoalan yang sering dihadapi oleh para remaja adalah perilaku seksual pra nikah. Adapun bentuk-bentuk tingkah laku ini bisa bermacam-macam, [3]“ ditemukan terdapat kemajuan dalam perilaku seksual, adapun bentuk-bentuk perilaku seksualnya seperti berciuman, ciuman lidah, memegang payudara, memegang penis, menyentuh vagina, hubungan seks, dan seks oral". Perilaku seksual pra nikah pada remaja bukan hal baru di dunia pendidikan. Sering kali berita-berita di media masa menyajikan informasi maupun berita terkait tentang terjadinya perilaku seksual pra nikah pada remaja. Bentuk perilaku seperti bercumbu, bersenggama, berciuman dan berhubungan seks untuk budaya barat merupakan hal yang tidak asing dan lumrah bagi mereka dalam melakukan perilaku seksual pra nikah, tetapi untuk budaya timur hal ini dilarang bagi remaja yang belum saatnya untuk melakukan perilaku seksual pra nikah larangan ini juga terdapat di dalam agama untuk melakukan perilaku seksual pra nikah karena termasuk dalam kategori dosa besar dan belum adanya ikatan pernikahan.

Perilaku manusia sebagian besar merupakan hasil dari pengalaman serta interaksi manusia dengan lingkungannya yang terwujud dalam pengetahuan, sikap, dan tindakan. Perilaku terbentuk melalui adanya pengetahuan dari informasi yang diberikan. Minimnya informasi dan juga pengetahuan yang diperoleh sehingga dapat memunculkan perilaku seksual yang tidak sehat dan tidak bertanggung jawab. Larangan yang diberikan yang tidak sesuai dengan pemberian pengetahuan akan informasi seksual yang tidak seimbang hanya akan merangsang serta mendorong siswa untuk mencoba-coba,tetapi juga menimbulkan salah penerimaan. Jauh lebih baik memberikan infomasi dengan menggunakan media agar siswa lebih paham tentang resiko perilaku seksual pra nikah untuk dapat mengatasi permasalahan yang dihadapi oleh siswa di sekolah dibutuhkan peranan guru bimbingan dan konseling.

Guru Bimbingan dan Konseling memberikan layanan bimbingan dan konseling, ada beberapa jenis layanan yang dapat diberikan salah satunya yang dapat diberikan adalah layanan informasi sebagaimana yang di kemukakan oleh [4] "layanan informasi adalah kegiatan memberikan pemahaman kepada individu-individu yang berkepentingan tentang berbagai hal yang diperlukan untuk menjalani suatu tugas atau kegiatan, atau untuk menentukan arah suatu tujuan atau rencana yang di kehendaki”.

Layanan informasi yang di berikan oleh guru bimbingan dan konseling, dapat memanfaatkan media audio visual dalam rangka mempermudah pemahaman siswa. Media merupakan alat bantu bagi guru bimbingan dan konseling dalam penyampaian pesan yang akan disampaikan kepada peserta didik secara langsung. Media audio visual merupakan salah satu alternatif solusi yang dapat diberikan kepada peserta didik agar pemahaman peserta didik dalam menerima informasi lebih cepat terserap dengan baik. [5] "mengatakan media audio visual adalah seperangkat alat yang dapat memproyeksikan gambar bergerak dan bersuara seperti televisi, VCD, sound slide dan film". Dengan adanya media audio visual dapat membantu bagi pendidik untuk menyampaikan informasi kepada peserta didik secara langsung. Disinilah layanan informasi dengan menggunakan media audio visual sangat berperan guna meningkatkan pemahaman siswa. Jika siswa sulit untuk mendapatkan informasi seksualitas melalui jalur formal, terutama lingkungan sekolah dan petugas kesehatan, maka kecenderungan yang muncul adalah mencoba mencari sumber informal.

SMA Negeri 2 Mempawah merupakan salah satu SMA yang sudah melaksanakan layanan bimbingan dan konseling. Namun layanan bimbingan dan konseling di rasakan belum cukup maksimal mengatasi masalah-masalah yang di hadapi oleh siswa SMA Negeri 2 Mempawah. Hal ini ditunjukkan dengan kurangnya perhatian orang tua terhadap anak-anak nya pada saat diundang hanya sebagian kecil yang datang hal ini di sebabkan oleh kesibukan serta kurangnya perhatian terhadap perkembangan perilaku anak-anak yang sudah menginjak remaja.

Berdasarkan hasil dari wawancara awal dengan guru bimbingan dan konseling di SMA Negeri 2 Mempawah hampir seluruh siswa dapat dikatakan sudah mengenal lawan jenis dan berpacaran baik dari siswa kelas X, XI, dan XII. Akhir-akhir ini guru-guru di SMA Negeri 2 Mempawah melihat anak didiknya berpacaran, sering berduaan, bergandengan tangan dengan lawan jenis dan juga merangkul bahu di lingkungan sekolah yang biasa terlihat di depan kelas bahkan di depan toilet. Pihak sekolah telah memberlakukan peraturan yang ketat yaitu mengembalikan siswa ke pihak orang tua (drop out) apabila diketahui ada siswa yang melakukan hubungan intim ataupun hamil. Berdasarakan data yang didapat lagi dari beberapa kelas yang ada di sekolah SMA Negeri 2 Mempawah ada satu kelas yang siswanya ketahuan berpacaran di sekolah berdua pada saat jam pelajaran, berpelukan, berciuman. Hal ini sudah mengarah pada perilaku seksual pra nikah dikalangan remaja di usia sekolah terutama tingkat SMA dapat menyebabkan beberapa resiko seperti terancam putus sekolah, cemoohan dari masyarakat, pernikahan dini dimana mental mereka masih labil, sehingga rentan perceraian, kehamilan diluar nikah kemudian aborsi yang mengancam nyawa, atau dapat pula terkena PMS (penyakit menular seksual).

Meningkatkan pemahaman resiko perilaku seksual pra nikah dapat dilakukan melalui layanan informasi dengan menggunakan media audio visual. Dalam pelaksanaan sebelum ini guru bimbingan dan konseling dalam memberikan layanan informasi masih menggunakan metode ceramah dan power point di depan kelas. Guru bimbingan dan konseling dapat menggunakan media bimbingan berupa media audio visual yaitu gambar bergerak dan bersuara 
seperti televisi, VCD, sound slide dan film dalam memberikan suatu layanan.

Berdasarkan latar belakang yang telah diuraikan diatas maka peneliti tertarik untuk meneliti tentang "Meningkatkan Pemahaman Resiko Perilaku Seksual Pra Nikah Melalui Layanan Informasi Dengan Media Audio Visual Siswa SMA Negeri 2 Mempawah".

\section{METODE}

Penelitian ini menggunakan metode penelitian tindakan bimbingan dan konseling (PTBK). [6] mengatakan "Prosedur penelitian tindakan bimbingan dan konseling terdapat 4 tahapan yang lazim dilalui yaitu: (1) Perencanaan, (2) Pelaksanaan, (3) Pengamatan, dan (4) Refleksi”.

Penelitian tindakan bimbingan dan konseling ini dilaksanakan pada bulan April 2018 bertempat di SMA Negeri 2 Mempawah dengan subjek penelitian yaitu 33 orang siswa. Teknik pengumpulan datanya menggunakan teknik observasi langsung, teknik komunikasi langsung, teknik komunikasi tidak langsung dan teknik dokumenter. Sedangkan alat pengumpulan datanya menggunakan studi dokumentasi, observasi, wawancara, dan skala psikologi yang selanjutnya dilakukan triangulasi data untuk menggali kebenaran informasi melalui sumber perolehan data yang berbeda.

Teknik analisa data dalam penelitian ini menggunakan analisis data kuantitatif dan kualitatif dengan langkahlangkahnya berupa pengumpulan dan penafsiran data serta penyimpulan hasil perolehan data penelitian.

\section{HASIL DAN PEMBAHASAN}

\section{A. HASIL}

Hasil studi pendahuluan yang dilakukan pada siswa SMA Negeri 2 Mempawah dengan responden 33 siswa menunjukkan bahwa aspek resiko psikologis (55\%) masuk kategori cukup, aspek resiko sosial (53\%) masuk kategori cukup, aspek resiko fisik (68\%) masuk kategori cukup, dan aspek resiko moral dan agama (58\%) masuk kategori cukup. Untuk mempermudah melihat secara visual pemahaman resiko perilaku seksual pra nikah siswa SMA Negeri 2 Mempawah, dapat disajikan dalam bentuk tabel berikut: TABEL I

HASIL SKALA PSIKOLOGIS PEMAHAMAN RESIKO PERILAKU SEKSUAL PRA NIKAH SEBELUM TINDAKAN

\begin{tabular}{cccccc}
\hline No & $\begin{array}{c}\text { Aspek } \\
\text { Variabel }\end{array}$ & $\begin{array}{c}\text { Skor } \\
\text { Aktual }\end{array}$ & $\begin{array}{c}\text { Skor } \\
\text { Ideal }\end{array}$ & \% & Kategori \\
\hline 1 & $\begin{array}{l}\text { Resiko } \\
\text { Psikologis }\end{array}$ & 1657 & 3036 & $55 \%$ & Cukup \\
2 & $\begin{array}{l}\text { Resiko Sosial } \\
3\end{array}$ & 417 & 792 & $53 \%$ & Cukup \\
4 & $\begin{array}{l}\text { Resiko Fisik } \\
\text { Resiko Moral } \\
\text { Dan Agama }\end{array}$ & 714 & 1056 & $68 \%$ & Cukup \\
\hline $\begin{array}{l}\text { Jumlah Persentase } \\
\text { Keseluruhan }\end{array}$ & 3398 & 5940 & $57 \%$ & Cukup \\
\hline
\end{tabular}

Berdasarkan penjelasan di atas, dapat digambarkan sebagaimana yang tertera dalam diagram 1 sebagai berikut:

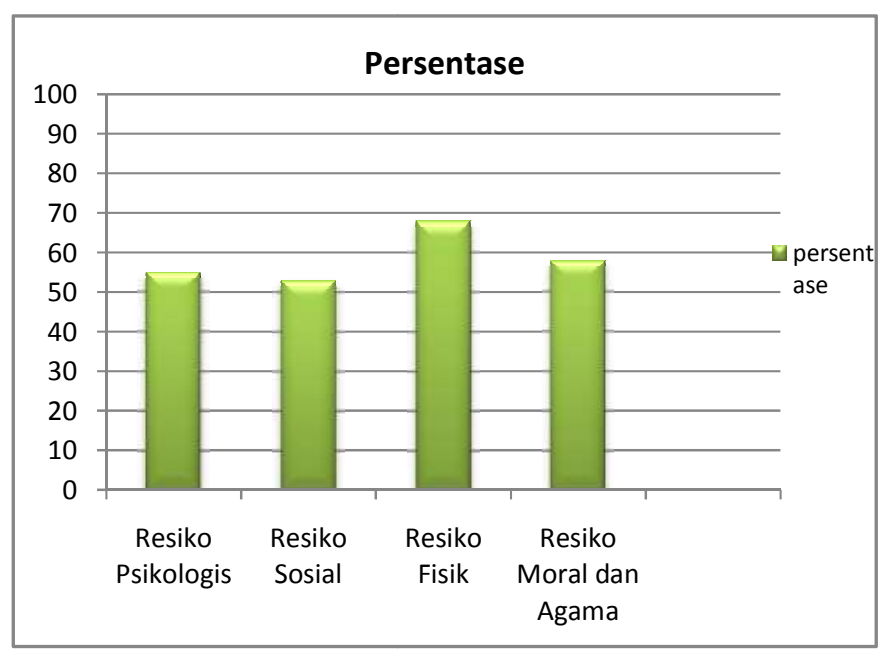

Diagaram 1 Persentase Skala Psikologis Pemahaman Resiko Perilaku Seksual Pra Nikah Sebelum Tindakan

Berdasarkan diagram di atas, dapat diketahui bahwa pemahaman resiko perilaku seksual pra nikah pada subyek penelitian sebelum di laksanakan layanan informasi dengan media audio visual pada siswa kelas XI IPS 1 SMA Negeri 2 Mempawah dalam kategori "cukup", dengan persentase keseluruhan $57 \%$. Hal ini terlihat dari hasil skala psikologis yang telah di isi oleh siswa sebelum dilaksanakannya layanan informasi dengan media audio visual, terdapat empat aspek yang berada dalam kategori "cukup". Oleh karena itu peneliti memberikan layanan informasi dengan media audio visual dengan harapan dapat meningkatkan pemahaman resiko perilaku seksual pra nikah.

\section{Siklus I}

1. Perencanaan Tindakan

Peneliti mempersiapkan materi yang akan disampaikan serta pedoman observasi yang akan digunakan dalam mengamati proses kegiatan yang akan dilaksanakan.

2. Pelaksanaan Tindakan

Peneliti melaksanakan layanan informasi terkait dengan materi resiko psikologis dan resiko sosial perilaku seksual pra nikah, namun hasil yang di dapat pada pertemuan pertama siswa masih banyak yang belum memahami materi yang di sampaikan sehingga peneliti melanjutkan ke pertemuan kedua pada pertemuan ini siswa sudah mulai menunjukkan keaktifannya untuk bertanya dan diskusi walaupun masih ada sebagian kecil yang kurang percaya diri dan malu-malu.

3. Pengamatan (observasi)

Berdasarkan observasi kegiatan layanan informasi dengan media audio visual dari paparan di atas dapat diambil kesimpulan yaitu pelaksanaan layanan informasi dengan media audio visual belum sepenuhnya berjalan dengan baik. Masih terdapat siswa yang masih malumalu dalam bertanya, dan kurang percaya diri, dan masih 
dalam kategori cukup. Terdapat kelemahan-kelemahan yang ditunjukan siswa seperti: masih ada siswa yang belum begitu aktif terlibat dalam kegiatan, malu-malu saat bertanya, kurang percaya diri.

\section{Refleksi}

Setelah tindakan siklus I dilaksanakan, peneliti kembali menyebar skala psikologis kepada subjek penelitian, penyebaran skala psikologis dilakukan setelah tindakan siklus I pertemuan kedua selesai dilaksanakan. Hal ini dilakukan untuk mengetahui sejauh mana peningkatan pemahaman resiko perilaku seksual pra nikah setelah diberikan layanan informasi dengan media audio visual pada siklus I. Berdasarkan dari hasil penyebaran skala psikologis terdapat peningkatan pemahaman perilaku seksual pra nikah setelah diberikan layanan informasi dengan media audio visual hal ini ditunjukkan dengan angka $65 \%$ dari $57 \%$ sebelum diberikan tindakan.

\section{Siklus II}

1. Perencanaan Tindakan

Pada siklus II terlebih dahulu peneliti membuat perencanaan tindakan. Pada tahap perencanaan ini peneliti berdiskusi dengan guru bimbingan dan konseling di SMA Negeri 2 Mempawah. Peneliti dan guru bimbingan dan konseling mempersiapkan materi yang akan disampaikan dalam mengamati proses kegiatan yang akan dilaksanakan serta menggunakan media yang tepat yaitu media audio visual guna untuk meningkatkan pemahaman resiko perilaku seksual pra nikah pada siswa.

2. Pelaksanaan Tindakan

Peneliti melaksanakan layanan informasi terkait dengan materi resiko fisik dan resiko moral dan agama perilaku seksual pra nikah, namun hasil yang di dapat pada pertemuan kedua siswa sudah sebagian besar memahami materi yang di sampaikan sehingga peneliti tidak perlu melanjutkan ke pertemuan berikutny. pada pertemuan ini siswa menunjukkan keaktifannya untuk bertanya dan diskusi walaupun masih ada sebagian kecil yang kurang percaya diri dan malu-malu.

3. Pengamatan (observasi)

Berdasarkan observasi kegiatan layanan informasi dengan media audio visual dari paparan di atas dapat diambil kesimpulan yaitu pelaksanaan layanan informasi dengan media audio visual sudah sepenuhnya berjalan dengan baik. Yaitu siswa dan peneliti dapat membina hubungan dengan baik dalam proses layanan, siswa sudah banyak aktif yang bertanya dan terlibat dalam proses pelaksanaan layanan dan percaya diri.

4. Refleksi

Setelah dilaksanakan tindakan penelitian siklus II peneliti kembali menyebarkan skala psikologis untuk mengetahui apakah pemahaman resiko perilaku seksual pra nikah siswa meningkat sesuai dengan harapan peneliti setelah diberikan layanan informasi dengan media audio visual. Berdasarkan dari hasil penyebaran skala psikologis layanan informasi dengan media audio visual yang telah di diskusikan dengan kolaborator bahwa pelaksanaan layanan tindakan siklus II telah terjadi peningkatan pemahaman resiko perilaku seksual pra nikah dengan mencapai hasil persentase $77 \%$ dengan kategori "baik" maka penelitian pun dihentikan karena sudah mencapai indikator keberhasilan yang diharapkan.

Berdasarkan hasil tindakan dan sebaran skala psikologis pada siklus I dan II terhadap pemahaman resiko perilaku seksual pra nikah terdapat peningkatan yang signifikan dari $57 \%$ sebelum diberi tindakan menjadi $63 \%$ pada tindakan siklus I dan meningkat menjadi $77 \%$ pada tindakan siklus II. Presentase skala psikologis pemahaman perilaku seksual pra nikah dapat dilihat pada diagram $2 \mathrm{di}$ bawah ini:

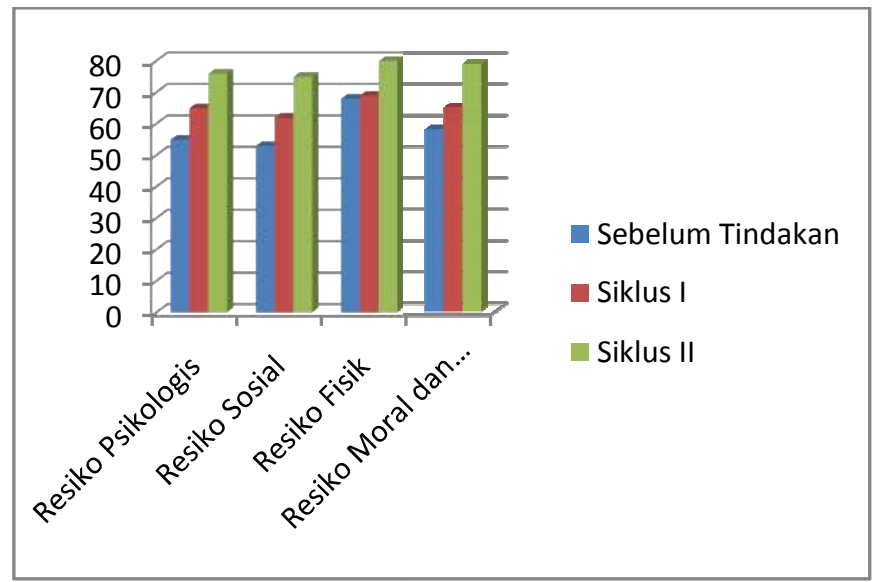

Diagram 2 Persentase Skala Psikologis Pemahaman Resiko Perilaku Seksual Pra Nikah Sebelum Dan Sesudah Pelaksanaan Tindakan Siklus I Dan II

Berdasarkan diagram di atas, terlihat perbandingan pemahaman resiko perilaku seksual pra nikah sebelum tindakan dan sesudah dilakukannya tindakan baik di siklus I maupun di siklus II terus mengalami peningkatan di setiap aspeknya.

\section{B. PEMBAHASAN}

Berdasarkan dari hasil pelaksanaan siklus I dan II, diperoleh kesimpulan bahwa melalui pelaksanaan layanan informasi dengan media audio visual dapat meningkatkan pemahaman resiko perilaku seksual pra nikah. Hal ini dapat dilihat dari analisis skala psikologis sebelum (pre test) di berikan tindakan dengan presentase $57 \%$ dengan kategori "cukup", dan dapat di interpretasikan bahwa siswa kelas XI IPS 1 SMA Negeri 2 Mempawah masih terdapat siswa yang belum memahami resiko perilaku seksual pra nikah seperti belum memahami resiko psikologis, resiko sosial, resiko fisik, dan resiko moral dan agama. Namun setelah dilaksanakan tindakan pada siklus I siswa menunjukkan peningkatan setelah dilaksanakan tindakan menjadi $65 \%$ dengan kategori "cukup" dengan besaran peningkatan $8 \%$, dan dapat di interpretasikan bahwa siswa kelas XI IPS 1 SMA Negeri 2 Mempawah, masih terdapat beberapa siswa yang belum aktif bertanya, masih ada siswa yang masih 
kurang memperhatikan saat peneliti menjelaskan dan masih terdapat beberapa siswa yang selalu terlihat malu mengemukakan pendapat. Setelah pelaksanaan siklus I maka peneliti merasa perlu untuk melanjutkan pada pelaksanaan tindakan pada siklus II setelah dilaksanakan tindakan di peroleh hasil 77\% dengan kategori "baik", dengan besaran peningkatan $12 \%$ dan dapat di interpretasikan bahwa siswa kelas XI IPS 1 SMA Negeri 2 Mempawah, siswa sudah memahami resiko yang menyebabkan perilaku seksual pra nikah.

Secara umum pemahaman siswa mengenai resiko perilaku seksual pra nikah dalam kategori "cukup". Pada pengamatan awal sebelum dilaksanakan penelitian terlihat bahwa siswa mempunyai tingkat pemahaman yang cukup, dan hasil sebelum diberikan tindakan menunjukkan tingkat pemahaman dengan kriteria cukup. Masih ada sebagian kecil siswa belum mengetahui keseluruhan resiko perilaku seksual pra nikah. Dari hasil penelitian di atas mengatakan bahwa layanan informasi dapat menigkatkan pemahaman resiko perilaku seksual pra nikah. Hal ini sejalan dengan pendapat [4] yang menyatakan bahwa layanan informasi merupakan pemahaman kepada individu-individu yang berkepentingan tentang berbagai hal yang diperlukan untuk menjalani suatu tugas atau kegiatan, atau untuk menentukan arah suatu tujuan atau rencana yang di kehendaki.

Setelah di berikan layanan informasi dengan menggunakan media audio visual berdasarkan hasil perhitungan skala psikologis yang di isi oleh siswa mengalami peningkatan. Siswa menunjukkan bahwa mereka memahami resiko perilaku seksual pra nikah. Hal ini sejalan dengan hasil kajian yang relevan menurut [7] menyatakan bahwa komitmen hubungan mempunyai pengaruh terhadap perilaku seksual pra nikah walaupun tidak besar pengaruhnya yang diberikan sikap terhadap perilaku seks pra nikah. Sedangkan [8] menyatakan pemahaman siswa tentang resiko perilaku seksual pra nikah setelah diberikan layanan informasi dengan media visual mendapatkan hasil 79\% dengan kateogir "baik". Dengan demikian dapat disimpulkan bahwa pemahaman resiko seksual pra nikah dapat di tingkatkan melalui layanan informasi dengan media audio visual siswa kelas XI IPS 1 SMA Negeri 2 Mempawah.

\section{KESIMPULAN}

Berdasarkan hasil penelitian dapat disimpulkan bahwa adanya peningkatan pemahaman resiko perilaku seksual pra nikah melalui layanan informasi dengan media audio visual siswa kelas XI IPS 1 SMA Negeri 2 Mempawah dengan kategori "baik". Hal ini dilihat dari analisis sebelum diberikan tindakan dengan kategori "cukup" dan dapat di interpretasikan bahwa siswa kelas XI IPS 1 SMA Negeri 2 Mempawah masih ada yang belum memahami dampak yang akan terjadi apabila melakukan perilaku seksual pra nikah seperti belum memahami resiko psikologis, resiko sosial, resiko fisik, dan resiko moral dan agama. Proses pelaksanaan layanan informasi dengan media audio visual dalam meningkatkan pemahaman resiko perilaku seksual pra nikah siswa kelas XI IPS 1 SMA Negeri 2 Mempawah, di lakukan dengan 3 tahap yaitu: kegiatan awal, kegiatan inti, kegiatan akhir. Pada pelaksanaan layanan informasi ini dinyatakan "Baik". Terdapat peningkatan pemahaman resiko perilaku seksual pra nikah siswa Kelas XI IPS 1 SMA Negeri 2 Mempawah sebelum diberikan layanan informasi dengan media audio visual dengan kategori "Cukup" dan mengalami peningkatan setelah dilaksanakan tindakan siklus I menjadi kategori "Cukup" dan meningkat lagi sesuai dengan harapan peneliti setelah dilaksanakan tindakan siklus II dengan kategori "Baik".

\section{DAFTAR PUSTAKA}

[1] Depdiknas. (2003). Undang-Undang Republik Indonesia Nomor 20 Tahun 2003, tentang Sistem Pendidikan Nasional.

[2] Sarwono, S.W. (2015). Psikologi Remaja. Jakarta: Rajawali Press.

[3] Santrock, J.W. (2012). Life-Span Development: Perkembangan Masa Hidup. Edisi ketiga belas. Jakarta: Penerbit Erlangga.

[4] Prayitno \& Erma, N. (2015). Dasar-Dasar Bimbingan dan Konseling. Jakarta: PT. Rineka Cipta.

[5] Sanaky, H.AH. (2013). Media Pembelajaran Interaktif-Inovatif. Yogyakarta: Safiria Insania Press.

[6] Hidayat, D. R. \& Badrujaman, A. (2012). Penelitian Tindakan dalam Bimbingan Konseling. Jakarta: PT Indeks.

[7] Rahardjo, W. dkk. (2017). Perilaku Seks Pranikah Pada Mahasiswa: Memiliki Peran Harga Diri, Komitmen Hubungan, Dan Sikap Terhadap Perilaku Seks Pranikah. Jurnal Psikologi. Fakultas Psikologi Universitas Gunadarma, 44,(2),139-152.

[8] Rahmawati, S. (2011). Meningkatkan Pemahanan Siswa Tentang Resiko Perilaku Seksual Pra Nikah Melalui Layanan Informasi dengan Menggunakan Media Visual Di Kelas IX SMP Negeri 4 Purbalingga Tahun Ajaran 2011/2012 (Doctoral dissertation, Universitas Negeri Semarang). 